Article

\title{
Cornus officinalis Ethanolic Extract with Potential Anti-Allergic, Anti-Inflammatory, and Antioxidant Activities
}

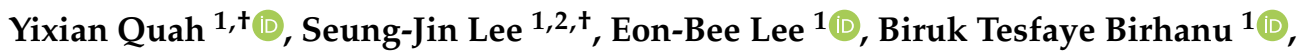 \\ Md. Sekendar Ali ${ }^{1,3,4}{ }^{1}$, Muhammad Aleem Abbas ${ }^{1}{ }^{(\mathbb{D}}$, Naila Boby ${ }^{1}{ }^{\mathbb{D}}, \mathrm{Zi}$-Eum $\operatorname{Im}^{5}$ and \\ Seung-Chun Park $1, *$ (D)
}

1 Laboratory of Veterinary Pharmacokinetics and Pharmacodynamics, College of Veterinary Medicine, Kyungpook National University, Daegu 41566, Korea; im.yixianquah@gmail.com (Y.Q.); dvmleesj@naver.com (S.-J.L.); eonbee@gmail.com (E.-B.L.); btbtes@gmail.com (B.T.B.); alipharm2000@gmail.com (M.S.A.); syedaleemabbas77@gmail.com (M.A.A.); nailaboby1584@gmail.com (N.B.)

2 Development and Reproductive Toxicology Research Group, Korea Institute of Toxicology, Daejeon 34114, Korea

3 Department of Biomedical Science and Department of Pharmacology, School of Medicine, Brain Science and Engineering Institute, Kyungpook National University, Daegu 41944, Korea

4 Department of Pharmacy, International Islamic University Chittagong, Kumira, Chittagong 4318, Bangladesh

5 Forest Resources Development Institute of Gyeongsangbuk-do, Andong-si, Gyeongsangbuk-do 36605, Korea; zium78@korea.kr

* Correspondence: parksch@knu.ac.kr; Tel.: +82-53-950-5964

+ These authors contributed equally to this work.

Received: 8 September 2020; Accepted: 27 October 2020; Published: 29 October 2020

\begin{abstract}
Atopic dermatitis (AD) is an allergic and chronic inflammatory skin disease. The present study investigates the anti-allergic, antioxidant, and anti-inflammatory activities of the ethanolic extract of Cornus officinalis (COFE) for possible applications in the treatment of AD. COFE inhibits the release of $\beta$-hexosaminidase from RBL-2H3 cells sensitized with the dinitrophenyl-immunoglobulin $\mathrm{E}$ (IgE-DNP) antibody after stimulation with dinitrophenyl-human serum albumin (DNP-HSA) in a concentration-dependent manner $\left(\mathrm{IC}_{50}=0.178 \mathrm{mg} / \mathrm{mL}\right)$. Antioxidant activity determined using 2,2-diphenyl-1-picrylhydrazyl (DPPH) radical scavenging activity, ferric reducing antioxidant power assay, and 2,2'-azino-bis(3-ethylbenzothiazoline-6-sulfonic acid) (ABTS) scavenging activity, result in $\mathrm{EC}_{50}$ values of $1.82,10.76$, and $0.6 \mathrm{mg} / \mathrm{mL}$, respectively. Moreover, the extract significantly inhibits lipopolysaccharide (LPS)-induced nitric oxide (NO) production and the mRNA expression of iNOS and pro-inflammatory cytokines (IL-1 $\beta$, IL- 6 , and TNF- $\alpha$ ) through attenuation of NF-kB activation in RAW 264.7 cells. COFE significantly inhibits TNF- $\alpha$-induced apoptosis in HaCaT cells without cytotoxic effects $(p<0.05)$. Furthermore, 2 -furancarboxaldehyde and loganin are identified by gas chromatography/mass spectrometry (GC-MS) and liquid chromatography with tandem mass spectrometry (LC-MS/MS) analysis, respectively, as the major compounds. Molecular docking analysis shows that loganin, cornuside, and naringenin 7-O- $\beta$-D-glucoside could potentially disrupt the binding of IgE to human high-affinity IgE receptors (FceRI). Our results suggest that COFE might possess potential inhibitory effects on allergic responses, oxidative stress, and inflammatory responses.
\end{abstract}

Keywords: anti-inflammatory activity; antioxidant activity; atopic dermatitis; Cornus officinalis; molecular docking; human high-affinity IgE receptors 


\section{Introduction}

Atopic dermatitis (AD) is an allergic and chronic skin inflammation condition characterized by pruritic eczema and mechanical skin injury caused by scratching, elevated serum IgE levels, and markedly increased immune cells levels (eosinophils, mast cells, and lymphocytes) [1]. Particularly, Thelper 2 (Th2) cells are involved in AD development [2]. Th2 cells release cytokines such as interleukin (IL)-4, IL-5, IL-10, and IL-13, resulting in the activation and proliferation of eosinophils and mast cells. The resultant itching, skin scratching, mechanical skin barrier injury, and activation of immune cells, lead to further Th2 cell activation and itching [3].

Cornus officinalis is a dogwood species native to Eastern Asia (Korea, China, and Japan). Its fruit has been used in traditional medicine for backache, hypertension, and polyuria in Korea [4]. The protective effect of $C$. officinalis, used in herbal mixture with four other plant extracts, against atopic dermatitis in BALB/C mice was recently reported [5]. The major component of the reported herbal mixture was C. officinalis extract, constituting $50 \%$ of the formulation. Besides, a recent review on this medicinal plant discussed its biological properties such as antioxidant, anti-inflammatory, renal and hepatic protective, antimicrobial, and immunomodulatory effects [6] which all play a substantial role in modulating pathological mechanism in AD.

Previous studies almost exclusively focused on the anti-atopic, antioxidant, and anti-inflammatory effects of the herbal mixture but not on C. officinalis used individually in the in vitro studies for AD. This study is the first to report the potency and efficacy of the anti-atopic effects of the $C$. officinalis extract in an in vitro model of AD.

\section{Materials and Methods}

\subsection{Sample Preparation and Extraction}

To prepare the ethanolic extract of C. officinalis, dried fruits of C. officinalis (50 g) (Sansooyoo, Korea) were extracted three times with $70 \%$ ethanol $(500 \mathrm{~mL})$ at $65{ }^{\circ} \mathrm{C}$ for $4 \mathrm{~h}$ using a heating mantle. The filtered supernatant was concentrated using a rotary evaporator. The dense supernatant was solidified with a vacuum freeze dryer. The yield of the ethanolic extraction of $C$. officinalis (COFE) was approximately $14.33 \%$ of the dried material. COFE was dissolved in dimethyl sulfoxide (DMSO, Sigma-Aldrich, St. Louis, MO, USA) and stored as a stock solution at $-20{ }^{\circ} \mathrm{C}$ until use.

\section{2. $\beta$-Hexosaminidase Release}

The inhibition of $\beta$-hexosaminidase release from a rat basophilic leukemia cell line (RBL-2H3) was evaluated using the method described by Juckmeta et al. [7] with some modifications. Briefly, RBL-2H3 cells were seeded at $5 \times 10^{5}$ cells $/ \mathrm{mL}$ and incubated for $1.5 \mathrm{~h}$. RBL-2H3 cells were sensitized with anti-dinitrophenyl-immunoglobulin E (anti-DNP IgE; $0.45 \mu \mathrm{g} / \mathrm{mL}$ ) and incubated for $24 \mathrm{~h}$. The cells were washed with Siraganian buffer. Siraganian buffer $(160 \mu \mathrm{L})$ was added and the cells were incubated for $10 \mathrm{~min}$ at $37^{\circ} \mathrm{C}$. Different concentrations of COFE $(20 \mu \mathrm{L})$ were added to each well to reach a final concentration of $0,0.003,0.01,0.03,0.1$, and $0.3 \mathrm{mg} / \mathrm{mL}$, then the cells were incubated for $10 \mathrm{~min}$. Next, $20 \mu \mathrm{L}$ of dinitrophenyl-human serum albumin (DNP-HSA, final concentration $10 \mu \mathrm{g} / \mathrm{mL}$ ) was added to each well and the cells were incubated for another $20 \mathrm{~min}$ to stimulate cell degranulation. The supernatants were transferred to 96 -well plates at $50 \mu \mathrm{L} /$ well and incubated with $50 \mu \mathrm{L}$ of $p$-nitrophenyl- $N$-acetyl-b-D-glucosaminide (PNAG, $1 \mathrm{mM}$ ) in $0.1 \mathrm{M}$ citrate buffer (pH 4.5) at $37^{\circ} \mathrm{C}$ for $3 \mathrm{~h}$. The reaction was stopped by the addition of $200 \mu \mathrm{L}$ of the stop solution. The absorbance was measured at $405 \mathrm{~nm}$. The percentage of $\beta$-hexosaminidase release was calculated as a percentage of the total $\beta$-hexosaminidase content. A brief experimental timeline of this assay is illustrated in Supplementary Figure S1. 


\subsection{Antioxidant Activity}

\subsubsection{2,2-Diphenyl-1-picrylhydrazyl (DPPH) Free Radical Scavenging Activity}

The extracts scavenging activity against DPPH free radicals was evaluated using the method described by Chang et al. [8]; ascorbic acid was used as a positive control. The presence of DPPH free radicals was measured at $517 \mathrm{~nm}$.

\subsubsection{Ferric Reducing Antioxidant Power (FRAP) Assay}

The ferric reducing ability of tissues was determined using a modified FRAP method [9]. The absorbance of the reaction mixture was read at $595 \mathrm{~nm}$. The results were expressed as $\mu \mathrm{M}$ Trolox equivalent (TE), as $E_{\max }$ value, which is the value at which the maximal effect of the sample was obtained, and as $\mathrm{EC}_{50}$ value, which is the TE of the sample required to cause a $50 \%$ reduction in the FRAP value.

\subsubsection{Trolox Equivalent Antioxidant Capacity (TEAC) Assay}

The TEAC levels were determined with the method of Rufino et al. [10], with modifications. Trolox (10-1000 $\mu \mathrm{mol}$ TE) was used to generate the standard curve. Ten microliters of each sample were added to $90 \mu \mathrm{L}$ of an ABTS ${ }^{\bullet}$ solution and the absorbance was measured at $734 \mathrm{~nm}$. The results were expressed in $\mu \mathrm{mol} \mathrm{TE}$, as $\mathrm{E}_{\max }$ value, and $\mathrm{EC}_{50}$ value, which is the $\mathrm{TE}$ of the sample required for the inhibition of $50 \%$ ABTS free radical activity.

\subsection{Nitric Oxide (NO) Assay}

RAW 264.7 cells (Korean Cell Line Bank, Seoul, Korea) at $4 \times 10^{5}$ cells/well were allowed to adhere for $24 \mathrm{~h}$ until $80 \%$ confluency was reached. After $30 \mathrm{~min}$ of treatment of different extract concentrations, the cells were incubated with lipopolysaccharide (LPS) treatment $(1 \mu \mathrm{g} / \mathrm{mL})$ for $18 \mathrm{~h}$. NO production in the cell culture medium was measured as nitrite $\left(\mathrm{NO}_{2}\right)$ at $540 \mathrm{~nm}$ and quantified from a standard curve generated from sodium nitrite $\left(\mathrm{NaNO}_{2}\right)$. A brief experimental timeline of this assay was illustrated in Supplementary Figure S1. The cytotoxicity of the extracts in RAW 264.7 cells was determined using an 3-(4,5-dimethylthiazol-2-yl)-2,5-diphenyl tetrazolium bromide (MTT) assay [11].

\subsection{Total RNA Extraction and Quantitative RT-PCR}

Total RNA was extracted from cells using TRIzol reagent and used for cDNA synthesis with the cDNA EcoDry Premix (Takara, Shiga, Japan). Relative mRNA levels were determined by cycler CFX96 (Bio-Rad). PCR amplification was performed in triplicate with the following specific primers: IL-1 $\beta$ forward (F): TGAGCACCTTCTTTTCCTTCA and reverse (R): TTGTCTAATGGGAACGTCACAC; IL-6 F: TAATTCATATCTTCAACCAAGAGG and R: TGGTCCTTAGCCACTCCTTC; TNF- $\alpha$ F: CTGTAG CCCACGTCGTAGC and R: GGTTGTCTTTGAGATCCATGC; iNOS F: TGTGGCTACCACATTG AAGAA and R: TCATGATAACGTTTCTGGCTCTT; and $\beta$-actin F: GTCATCACTATTGGCAACGAG and R: TTGGCATAGAGGTCTTTACGG. Real-time PCR (RT-PCR) was performed using the following cycling conditions: enzyme activation and initial denaturation for $5 \mathrm{~min}$ at $95^{\circ} \mathrm{C}$ and 40 cycles of amplification at $95{ }^{\circ} \mathrm{C}$ for $10 \mathrm{~s}$ followed by $55^{\circ} \mathrm{C}$ (IL-1 $\beta$ and IL-6), $58{ }^{\circ} \mathrm{C}$ (iNOS), or $62{ }^{\circ} \mathrm{C}(\mathrm{TNF}-\alpha)$ for $20 \mathrm{~s}$.

\subsection{Western Blot Analysis}

RAW 264.7 cells were treated for $60 \mathrm{~min}$ with COFE $(0-0.3 \mathrm{mg} / \mathrm{mL})$ and then treated with LPS $(1 \mu \mathrm{g} / \mathrm{mL})$ for $30 \mathrm{~min}$ (for IkB $\alpha$ and p-p65 protein determination), or treated with LPS $(1 \mu \mathrm{g} / \mathrm{mL})$ for $18 \mathrm{~h}$ (for iNOS protein determination) (Supplementary Figure S1). At the end of the LPS treatment, Western blot analysis was conducted according to a reported method [12], with slight modification. Briefly, after washing cells with ice-cold PBS, total proteins were extracted from the cell pellets using 
the PRO-PREP protein extraction solution (iNtRON Biotechnology, Seongnam, Korea) according to the manufacturer's instruction. The lysates were centrifuged at $16,000 \times \mathrm{g}$ for $10 \mathrm{~min}$ at $4{ }^{\circ} \mathrm{C}$ and stored at $-20^{\circ} \mathrm{C}$ until use. Protein was then measured using the Pierce ${ }^{\mathrm{TM}} \mathrm{BCA}$ assay kit (ThermoFisher Scientific, Waltham, United States), with bovine serum albumin as a standard and then separated by sodium dodecyl sulfate polyacrylamide gel electrophoresis (SDS-PAGE) in 10\% gels, and transferred to polyvinylidene fluoride (PVDF) membranes. Membranes were blocked with $5 \%$ bovine serum albumin (BSA) in tris-buffered saline with tween-20 (TBST) for $1 \mathrm{~h}$ at room temperature followed by incubating with appropriate primary antibodies for $90 \mathrm{~min}$ at room temperature. Membranes were washed three times and incubated for an additional $60 \mathrm{~min}$ with horseradish peroxidase-conjugated secondary antibody. The expression of IkB $\alpha$ and p-p65 (1:1000) (both were purchased from Cell Signaling Technology, Danvers, MA, USA) and $\beta$-actin (Santa Cruz Biotechnology, Dallas, TX, USA) as a loading control were visualized using Thermo Scientific ${ }^{\mathrm{TM}}$ Pierce $^{\mathrm{TM}}$ ECL Western Blotting Substrate (ThermoFisher Scientific, Waltham, MA, USA).

\subsection{Flow Cytometric Analysis}

The MTT assay was used to examine the cytotoxicity of COFE in HaCaT cells [11]. The absorbance was measured at $570 \mathrm{~nm}$. After TNF- $\alpha(20 \mathrm{ng} / \mathrm{mL})$ treatment for $1 \mathrm{~h}$, the cells were incubated with different extract concentrations for $18 \mathrm{~h}$. The activation of caspases 3 and 7 in HaCaT cells was detected using the Muse Caspase-3/7 assay kit with a Muse Cell Analyzer (EMD Millipore, Billerica, MA, USA) according to the manufacturer's protocol. The data from the Muse Cell Analyzer were analyzed using Muse 1.4 software (Luminex Corporation, Austin, TX, USA). A brief experimental timeline of this assay was illustrated in Supplementary Figure S1.

\subsection{Gas Chromatography/Mass Spectrometry (GC-MS) and Liquid Chromatography with Tandem Mass Spectrometry (LC-MS/MS) Analysis}

The GC-MS analysis of COFE was performed by using an HP 6890 Plus GC gas chromatograph with a mass selective detector (MSD; HP 5973, Hewlett-Packard, California, United States). The samples were diluted 1:1000 (v:v) with HPLC-grade dichloromethane. The samples $(1 \mu \mathrm{L})$ were injected into an HP- 5 column. The GC oven temperature was set at $50{ }^{\circ} \mathrm{C}$ for $4 \mathrm{~min}$, increased to $280{ }^{\circ} \mathrm{C}$ at a rate of $4{ }^{\circ} \mathrm{C} / \mathrm{min}$, and held at the final temperature for $2 \mathrm{~min}$. The velocity of the carrier gas, $99.99 \% \mathrm{He}$, was $0.7 \mathrm{~mL} / \mathrm{min}$. Quantitative analysis was performed by using the area normalization method.

LC-MS analysis was performed on a Thermo Accela UHPLC system (Thermo Fisher Scientific, San Jose, CA, USA). The samples were separated on a Waters BEH C18 column $(2.1 \times 150 \mathrm{~mm}, 1.7 \mu \mathrm{m})$ at room temperature. The mobile phase consisted of water (A) and acetonitrile (B), both with $0.1 \%$ formic acid added. The elution gradient was set as follows: 5\% B (0 min), 5\% B (1 min), 70\% B (20 min), $100 \%$ B (24 min), and 100\% B (27 min). The flow rate was $400 \mu \mathrm{L} / \mathrm{min}$ and the sample loading volume was $1 \mu \mathrm{L}$. The UHPLC was coupled to an LTQ-Orbitrap XL hybrid mass spectrometer (Thermo Electron, Bremen, Germany) via an ESI interface. The samples were analyzed in positive ion mode and the conditions of the ESI source were the same as previously used [13].

\subsection{In Vivo Toxicity Evaluation}

Ten female 8-week-old Sprague-Dawley rats were obtained from Orient Bio Inc. (Gyeonggi-do, Korea). The acute toxicity study was performed by using a previously reported method [14] with slight modifications. Five rats per group were randomly assigned to the control and test groups. A single dose of COFE ( $2000 \mathrm{mg} / \mathrm{kg}$ of body weight) was administered intragastrically according to the OECD test guideline 423 [15]. A standard pellet diet (Hyochang Science, Daegu, Korea) and distilled water were provided ad libitum. The animals were under constant observation for abnormal signs and symptoms for the first $12 \mathrm{~h}$ after COFE administration and subsequently observed once per day for 2 weeks. The changes in body weight and food and water intake were measured twice a week 
for 14 days after treatment. The animals were sacrificed after the experimental period and the major organs were collected and inspected for gross lesions.

\subsection{Molecular Docking}

To investigate the binding mode of the loganin, cornuside, and naringenin $7-\mathrm{O}-\beta$-D-glucoside to human high-affinity IgE receptors (FceRI), a molecular docking analysis was performed using the FceRI-IgE complex structure data with the protein data bank (PDB) [16] ID 2Y7Q [17]. The conformations of loganin (ZINC000003978792) and naringenin 7-O- $\beta$-D-glucoside (ZINC4097895) were generated using a conformational search against the ZINC docking database, University of California, San Francisco (UCSF). The cornuside (InChI Key: SMTKSCGLXONVGL-UHFFFAOYSA-N) conformation was searched against the PubChem database. The ligand file in Structure Data File (SDF) format was converted to MOL format using the Openbabel software. The co-crystallized structures were prepared using UCSF Chimera (Chimera, Version 1.12, RBVI, San Francisco, CA, USA) and iGEMDOCK (Version 2.1; NCTU, Hsinchu City, Taiwan). Molecular docking was performed using iGEMDOCK with the accurate docking mode. The best-docked poses were further analyzed, and 3D structure images were prepared using UCSF Chimera.

\subsection{Statistical Analysis}

The $\mathrm{IC}_{50}$ and $\mathrm{EC}_{50}$ values were calculated using Prism (GraphPad Software Inc., La Jolla, CA, USA). Statistical differences were assessed by one-way analysis of variance and Duncan's multiple comparisons test using Statistical Analysis Systems software (SAS Institute, Cary, NC, USA). Values of $p<0.05$ were considered statistically significant.

\section{Results}

\subsection{Effect of COFE on DNP/IgE-Induced Degranulation in RBL-2H3 Cells}

COFE suppressed the release of $\beta$-hexosaminidase from RBL-2H3 cells in a concentration-dependent manner (Figure 1A). A dose of $0.3 \mathrm{mg} / \mathrm{mL}$ of COFE significantly inhibited $\beta$-hexosaminidase release $(46 \%)$ $(p<0.05)$. The $\mathrm{IC}_{50}$ value of COFE for $\beta$-hexosaminidase release inhibition was $0.178 \mathrm{mg} / \mathrm{mL}$, showing that the potential anti-atopic activity occurred through the suppression of the IgE-induced degranulation of RBL-2H3 cells.

\subsection{Antioxidant Activity of COFE}

Supplementary Figure S2 shows the DPPH radical scavenging activity of COFE. COFE showed concentration-dependent DPPH radical scavenging activity from 0.1 to $10 \mathrm{mg} / \mathrm{mL}$. Its $\mathrm{EC}_{50}$ value was $1.82 \mathrm{mg} / \mathrm{mL}$, which is approximately six times higher than that of ascorbic acid $(0.30 \mathrm{mg} / \mathrm{mL})$. The $E_{\max }$ values of COFE were $3.15 \mathrm{mM}$ TE and $3.23 \mathrm{mM}$ TE in the FRAP assay and ABTS assay, respectively. Its $\mathrm{EC}_{50}$ values were $10.76 \mathrm{mg} / \mathrm{mL}$ and $0.60 \mathrm{mg} / \mathrm{mL}$ in the FRAP assay and ABTS assay, respectively.

\subsection{Effect of COFE on LPS-Induced NO Production and Pro-Inflammatory Cytokines in RAW 264.7 Cells}

COFE significantly inhibited LPS-induced NO production in RAW 264.7 cells in a concentration-dependent manner $(0.01-0.3 \mathrm{mg} / \mathrm{mL})(p<0.05)$ with an $\mathrm{EC}_{50}$ value of $0.74 \mathrm{mg} / \mathrm{mL}$ (Figure 1B). Similarly, COFE attenuated LPS-induced iNOS mRNA expression in RAW 264.7 cells in a concentration-dependent manner, indicating a positive correlation between the inhibition of NO production and the suppression of iNOS mRNA expression (Figure 1C). At the tested concentrations, COFE did not exert any cytotoxic effects on RAW 264.7 cells (data not shown). Furthermore, COFE inhibited LPS-induced IL-1 $\beta$, IL-6, and TNF- $\alpha$ mRNA expression in RAW 264.7 cells in a concentration-dependent manner $(0.01-0.3 \mathrm{mg} / \mathrm{mL})$, with $\mathrm{E}_{\max }$ values ranging from $73 \%$ to $90 \%$ (Figure 1D). Furthermore, the $\mathrm{EC}_{50}$ values for the inhibition of IL-1 $\beta$, IL-6, and TNF- $\alpha$ were 0.0007 , 0.039 , and $0.006 \mathrm{mg} / \mathrm{mL}$, respectively. 
A
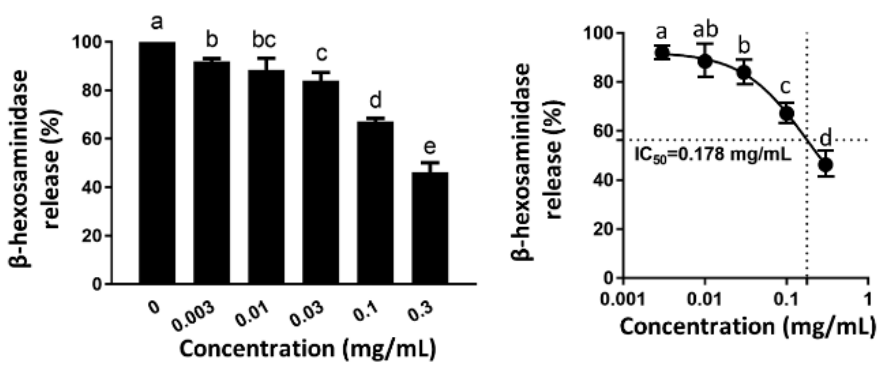

B

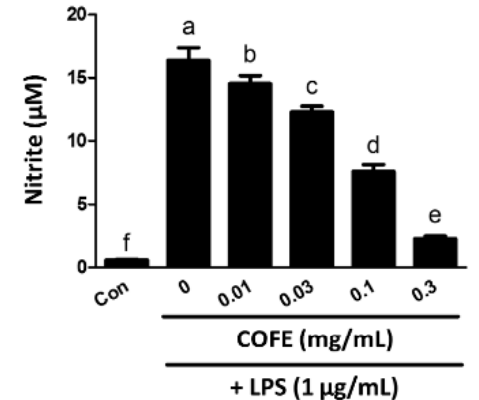

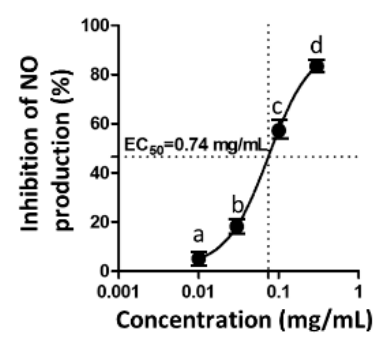

C
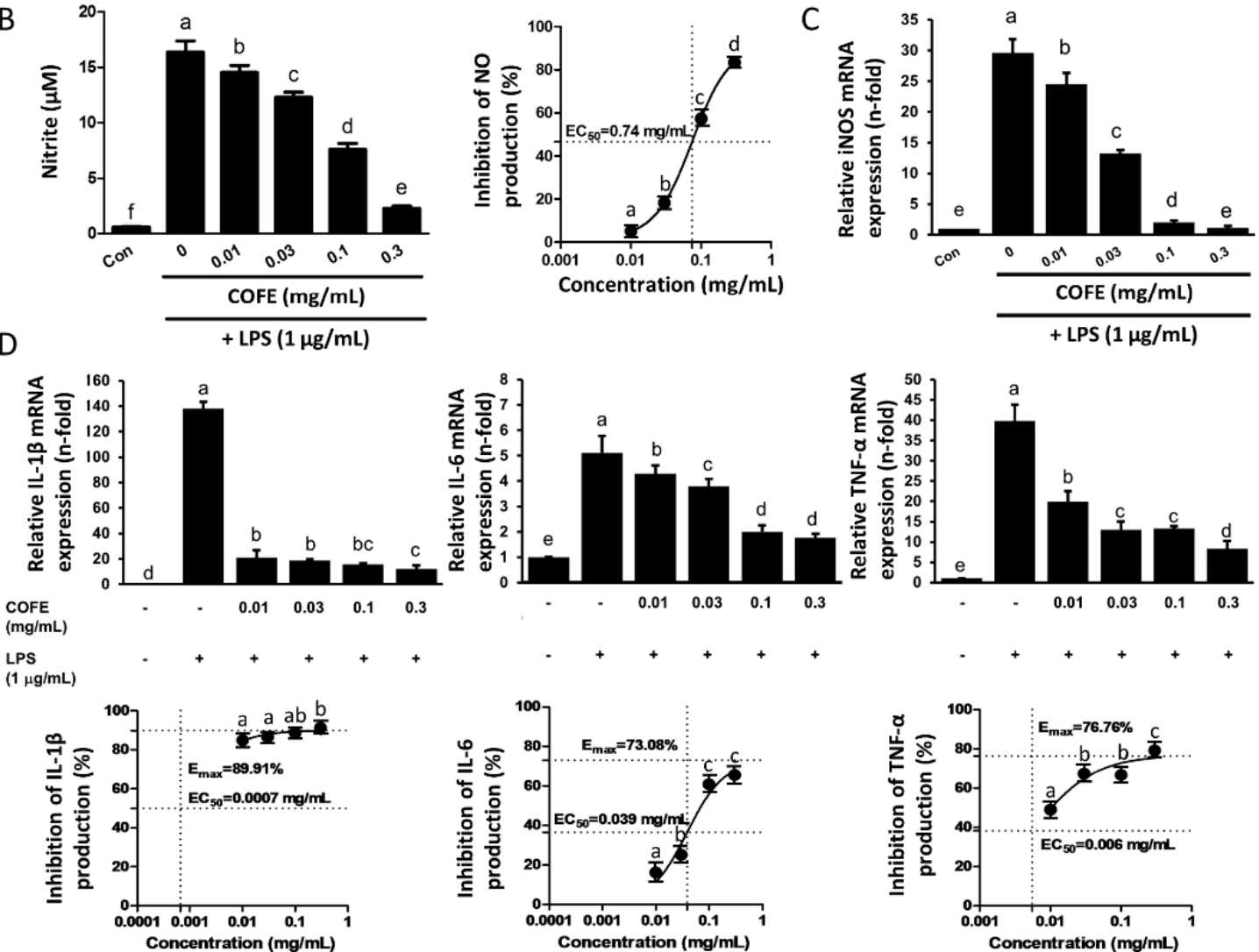

Figure 1. Anti-allergic and anti-inflammatory activity of ethanolic extract of Cornus officinalis (COFE). (A) Evaluation of the $\beta$-hexosaminidase release from RBL-2H3 cells treated with COFE (left) and the $\mathrm{IC}_{50}$ of COFE for $\beta$-hexosaminidase release (right). (B) Effect of COFE on lipopolysaccharide (LPS)-induced nitric oxide (NO) production. (C) iNOS mRNA expression. (D) Anti-inflammatory cytokine gene expression. Values are expressed as the mean \pm SD of three independent experiments. Letters $(\mathrm{a}-\mathrm{e})$ indicate significantly different values $(p<0.05)$, as determined by Duncan's multiple comparison test.

\subsection{Effect of COFE on NF- $\kappa B$ Stimulation}

Western blot analysis showed that LPS reduced the cytosolic IкB $\alpha$ expression but COFE increased it in a concentration-dependent manner (Figure 2A). Comparably, COFE inhibited LPS-induced cytosolic p-p65 expression. The expression of iNOS protein also showed significant reduction compared to the LPS induced group (Supplementary Figure S3). Thus, the anti-inflammatory activity of COFE occurs through the inhibition of NF- $\mathrm{kB}$ activation. 
A
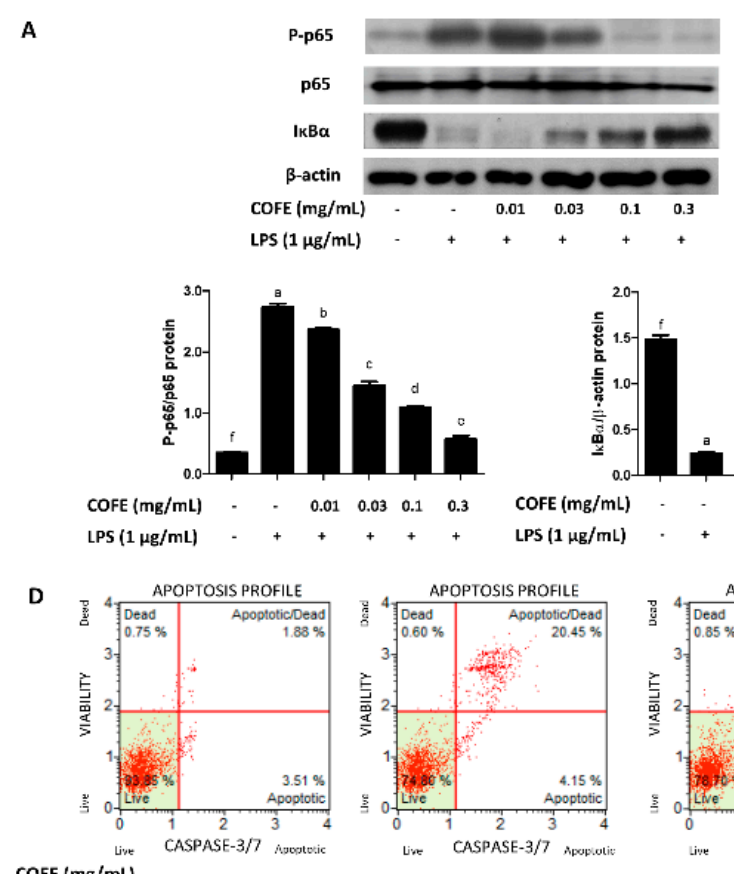

COFE $(\mathrm{mg} / \mathrm{mL})$

TNF- $\alpha(\mathrm{ng} / \mathrm{mL})$

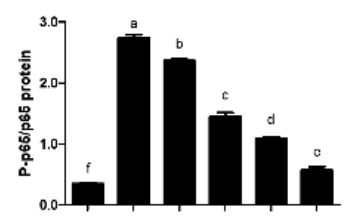

$\begin{array}{llll}0.01 & 0.03 & 0.1 & 0.3\end{array}$ $+++$

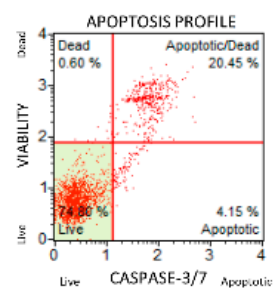

20

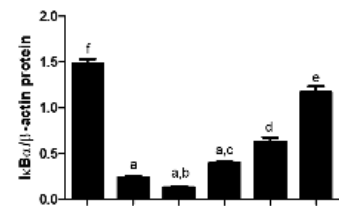

$\begin{array}{llll}0.01 & 0.03 & 0.1 & 0.3\end{array}$

$+++++$

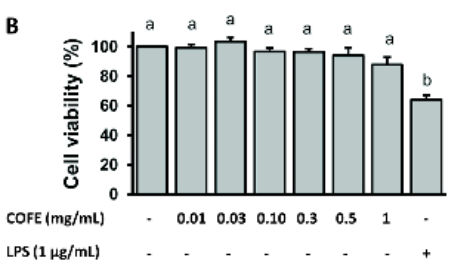

c

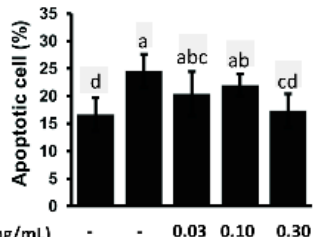

COFE $(\mathrm{mg} / \mathrm{mL})$ TNF- $\alpha(n g / m L)$ $\begin{array}{llll}20 & 20 & 20 & 20\end{array}$

Figure 2. Effect of COFE on LPS-induced NF-kB activation in RAW 264.7 cells (A), cell viability (B), and TNF- $\alpha$-induced apoptotic death in HaCaT cells (C,D). (A) Cells were treated with COFE $(0-0.3 \mathrm{mg} / \mathrm{mL})$ for $60 \mathrm{~min}$ and then treated with LPS $(1 \mu \mathrm{g} / \mathrm{mL})$ for $30 \mathrm{~min}$. The levels of total IкB $\alpha$ and phospho-p65 (P-p65) were determined by Western blotting of the total protein of cell lysates $(n=3)$. $\beta$-actin was used as a loading control. (B) The viability of HaCaT cells treated with increasing concentrations of COFE $(0-1 \mathrm{mg} / \mathrm{mL})$ for $24 \mathrm{~h}$ was evaluated using an MTT assay; LPS was used as a control. Each sample was assayed in triplicate at each concentration. (C) After TNF- $\alpha$ (20 ng/mL) treatment for $1 \mathrm{~h}$, cells were incubated with the indicated concentrations of extract for $18 \mathrm{~h}$. TNF- $\alpha$-induced apoptosis was detected by flow cytometric analysis. The data show healthy cells (annexin-V negative and caspase 3/7 and 7-ADD negative (lower left)), early apoptotic cells (positive for annexin- $\mathrm{V}$ and caspase 3/7 and negative for 7-ADD (lower right)), late apoptotic/dead cells (both annexin $\mathrm{V}$ and caspase 3/7 and 7-ADD positive (upper right)), and necrotic cells (only 7-ADD positive (upper left)) $(n=3)$. (D) Total apoptotic cells (early apoptotic and late apoptotic cells) were quantified by positive staining for annexin- $\mathrm{V}$ or caspase $3 / 7$ activity. Values are expressed as the mean \pm SD of three independent experiments. Letters $(a-f)$ indicate significantly different values $(p<0.05)$, as determined by Duncan's multiple comparison test.

\subsection{Effect of COFE on TNF- $\alpha$ Induced Apoptosis in HaCaT Cells}

To assess the suitability of COFE for the treatment of human AD, cytotoxicity and apoptosis were examined in human keratinocytes. Treating HaCaT cells with COFE (0-1 mg/mL) for $24 \mathrm{~h}$ did not affect their viability (Figure 2B). The impact of COFE on TNF- $\alpha$-induced apoptosis in HaCaT cells was evaluated through cytofluorometric analysis. TNF- $\alpha$-induced apoptosis was estimated through the net change in the percentage of total apoptotic cells compared with the controls (Figure 2C). After caspase 3/7 antibody treatment, TNF- $\alpha$-treated samples exhibited approximately $1.5 \times$ apoptotic/dead and apoptotic cells in comparison with untreated cells (Figure 2D). COFE significantly reduced TNF- $\alpha$-induced cell apoptosis $(p<0.05)$.

\subsection{Identification of the Constituent Compounds of COFE}

Table 1 shows the main constituents of COFE identified by GC-MS analysis, namely 4,6-cycloheptatrien-1-one, malic acid, 2-furancarbox-aldehyde, and 2,3-dihydro-3,5-dihydroxy- 
6-methyl-4H-pyran-4-one. The compounds responsible for the physiological effects in COFE were analyzed by LC-MS/MS and identified as loganin, cornuside, and naringenin 7-O- $\beta$-D-glucoside (Figure 3A). Loganin, a natural flavonoid, was the major component of COFE.

Table 1. Gas chromatography/mass spectrometry (GC-MS) analysis of compounds of the ethanolic extract of C. officinalis.

\begin{tabular}{ccccc}
\hline $\begin{array}{c}\text { RT } \\
\text { (Retention Time) }\end{array}$ & Formula & \% & ID & Activity \\
\hline 34.21 & $\mathrm{C}_{6} \mathrm{H}_{8} \mathrm{O}_{4}$ & 4.58 & $\begin{array}{c}\text { 2,3-dihydro-3,5-dihydroxy-6- } \\
\text { methyl-4H-pyran-4-one }\end{array}$ & $\begin{array}{c}\text { Antimicrobial, } \\
\text { anti-inflammatory, } \\
\text { antiproliferative }\end{array}$ \\
\hline 38.23 & $\mathrm{C}_{6} \mathrm{H}_{6} \mathrm{O}_{3}$ & 39.9 & 2-furancarboxaldehyde & $\begin{array}{c}\text { Antimicrobial, } \\
\text { preservative }\end{array}$ \\
\hline 43.38 & $\mathrm{C}_{4} \mathrm{H}_{6} \mathrm{O}_{5}$ & 9.71 & Malic acid & Antimicrobial \\
\hline 50.41 & $\mathrm{C}_{7} \mathrm{H}_{6} \mathrm{O}$ & 1.41 & 2,4,6-cycloheptatrien-1-one & Antioxidant \\
\hline
\end{tabular}
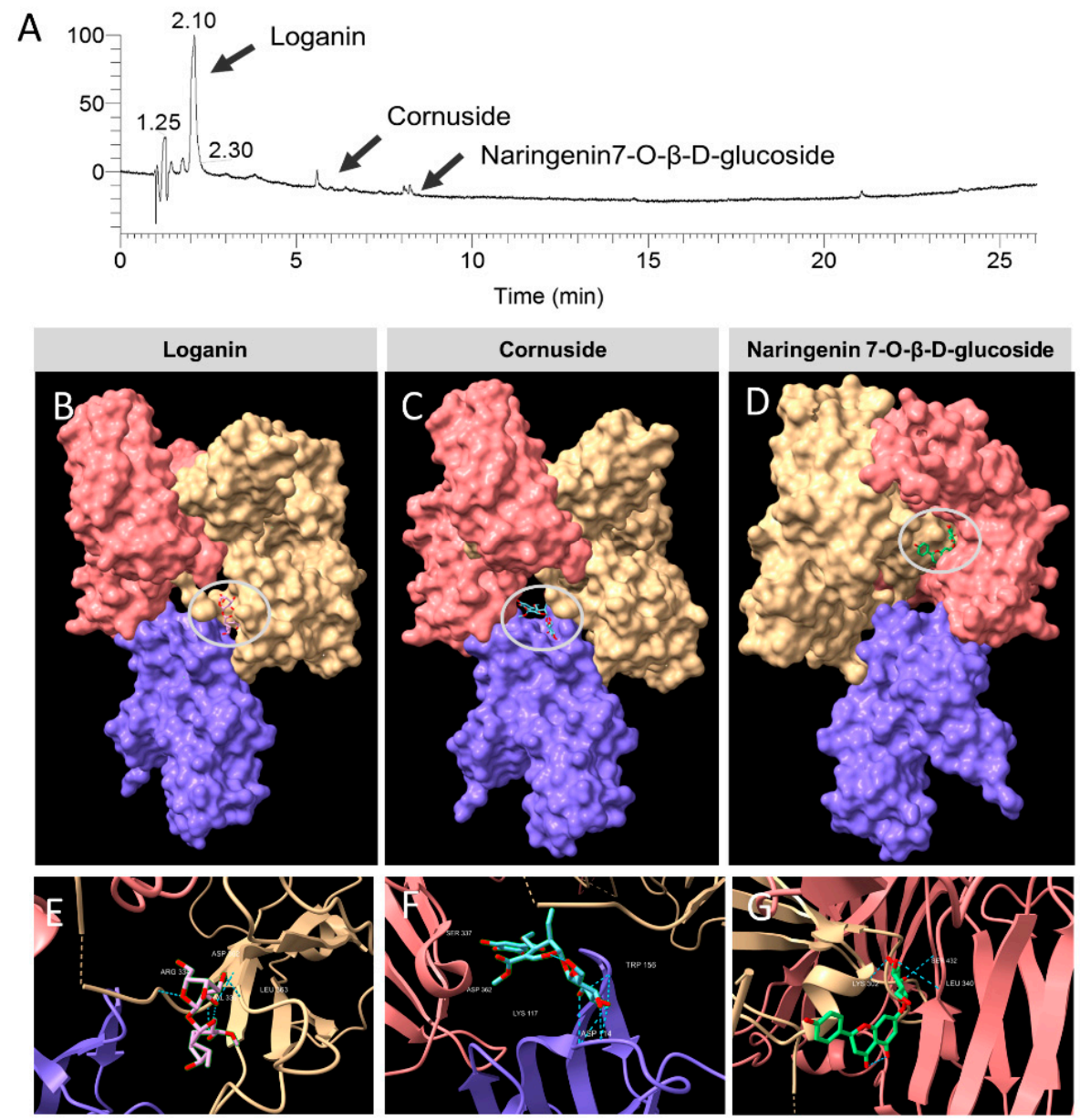

Figure 3. Liquid chromatography with tandem mass spectrometry (LC-MS/MS) COFE (A) and molecular docking analysis of the FceRI-IgE complex (B-G). The best-docked position showing the interaction sites of loganin (B), cornuside (C), and naringenin $7-\mathrm{O}-\beta$-D-glucoside (D) in the FceRI-IgE complex. The blue dotted lines represent the hydrogen bonds between the amino acid residues of the FceRI-IgE complex and loganin (ARG334, VAL336, ASP362, LEU363, ALA364), cornuside (SER337, ASP362, LYS117, ASP114, TRP156), and naringenin 7-O- $\beta$-D-glucoside (LYS302, ARG342, LEU340, ARG431, ALA338) (E-G). 


\subsection{In Vivo Toxicity Evaluation of COFE}

Animals displayed no clinical signs or mortality up to 14 days after the administration. The same procedure was carried out on three female rats and a similar observation was obtained. Therefore, the acute toxic class method, following the flow chart of $\mathrm{LD}_{50}$ cut-off, confirmed COFE as a category 5 substance in the Globally Harmonized System of Classification and Labeling of Chemicals (GHS).

\subsection{Molecular Docking}

By integrating the data obtained from LC-MS analysis with the in silico molecular docking analysis, the major bioactive components (loganin, cornuside, and naringenin 7-O- $\beta$-D-glucoside) found in COFE were found to interact with the FceRI-IgE complex. Figure 3B-D shows the loganin, cornuside, and naringenin 7-O- $\beta$-D-glucoside binding to the 3D structure of the FceRI-IgE complex. Figure $3 \mathrm{E}-\mathrm{G}$ shows the amino acid residues associated with the binding of the compounds through hydrogen bonding. The binding energies of the FceRI-IgE complex with the compounds according to molecular docking analysis are shown in Table 2.

Table 2. Binding energies (Kcal) between the FceRI-IgE complex and the bioactive compounds identified in COFE.

\begin{tabular}{ccccc}
\hline Compound & $\begin{array}{c}\text { Binding } \\
\text { Energy (Kcal) }\end{array}$ & Van der Waals & $\begin{array}{c}\text { Hydrogen } \\
\text { Bond }\end{array}$ & Electrostatic \\
\hline Loganin & -116.9 & -90.5332 & -26.3531 & 0 \\
Cornuside & -141.1 & -101.645 & -39.4547 & 0 \\
Naringenin 7-O- $\beta$-D-glucoside & -125.7 & -96.4237 & -29.3185 & 0 \\
\hline
\end{tabular}

\section{Discussion}

The anti-allergic potential of COFE was assessed with RBL-2H3 cells (Figure 1), which are commonly used to study allergy and inflammation reactions because they express high-affinity IgE receptors (FceRI) [5]. $\beta$-Hexosaminidase was used as an indicator of degranulation in RBL-2H3 cells sensitized by exposure to IgE-DNP antibody after stimulation with DNP-HSA [18]. Our results show COFE inhibits $\beta$-Hexosaminidase release with an $\mathrm{IC}_{50}$ of $0.178 \mathrm{mg} / \mathrm{mL}$ which is about 60 - and 1.4 -fold lower than that of ethanol extracts from mulberry fruit [19] and Arctium lappa fruit [20], respectively. Antioxidants potentially exert beneficial effects in the treatment of AD by inhibiting the oxidative stress which is involved in the pathophysiology of the acute exacerbation of AD [21]. However, the antioxidant activity of COFE was lower than that reported by Hwang and co-workers [4]. This may be due to the concentration of bioactive compounds in the plant, which could be influenced by photoperiodic, temperature, and geographical differences [22].

Macrophages play crucial roles in acute inflammation and persistence of proinflammatory cytokines, which lead to chronic inflammation conditions including AD [23]. We found that COFE significantly inhibits LPS-induced NO production, iNOS mRNA expression (Figure 1B,C), and iNOS protein expression in RAW 264.7 cells (Figure S3). Besides, COFE consistently suppresses the expression of IL-1 $\beta$, IL-6, and TNF- $\alpha$, suggesting that the upstream signaling molecules (such as NF-KB) could be the determining step in the anti-inflammatory response induced by COFE (Figure 4). Further studies are needed to confirm the use of COFE as a therapeutic agent for AD and various inflammatory diseases through the reduction of pro-inflammatory cytokines. Several plant extracts with potential anti-inflammatory activity may be suitable for the treatment of immune disorders like AD [24]. 


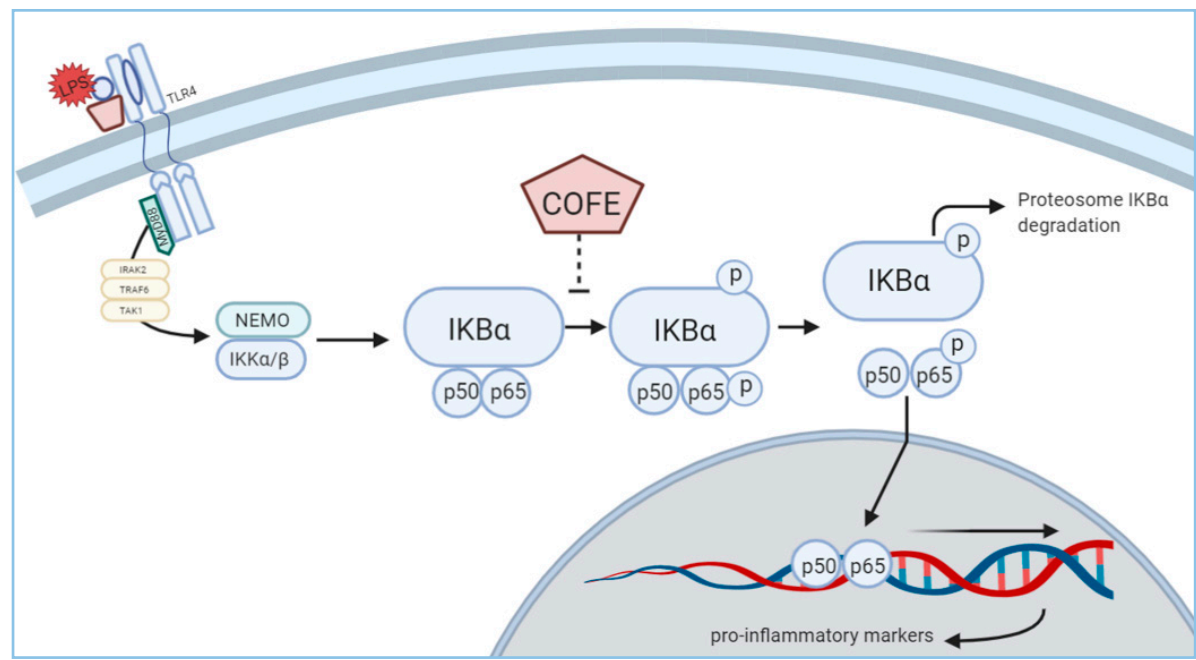

Figure 4. Illustration of the mechanism of action of COFE through NF-kB suppression in RAW 264.7 cells treated with LPS. TLR4: Toll-like receptor 4; IRAK2: Interleukin 1 Receptor Associated Kinase 2; TRAF6: Tumor necrosis factor receptor (TNFR)-associated factor 6; TAK1: Transforming growth factor $\beta$-activated kinase 1; MyD88: Myeloid differentiation primary response 88; NEMO: nuclear factor kappa-B essential modulator; IKK $\alpha / \beta$ : inhibitor of nuclear factor kappa-B kinase subunit $\alpha / \beta ; \mathrm{IKB} \alpha$ : nuclear factor of kappa light polypeptide gene enhancer in B-cells inhibitor alpha; p65/p50: nuclear factor NF-kappa-B p65/p50 subunit.

COFE significantly inhibited TNF- $\alpha$-induced apoptosis in HaCaT cells. TNF- $\alpha$ and pro-inflammatory cytokines are secreted by macrophages and mast cells and promote apoptosis in $\mathrm{HaCaT}$ cells by binding to the TNF-receptor 1 [25]. Considering the deterioration of skin lesions by inflammatory mediators that are released from various skin cells during the inflammatory process, COFE could be useful for the management of $\mathrm{AD}$ without acute oral toxicity.

Oxidative stress is associated with chronic skin inflammation and plays a role in the pathogenesis of AD [26]. Reactive oxygen species (ROS) can modify DNA, lipids, and proteins [26]. NO production is one of the biomarkers of lipid peroxidation resulting from oxidative stress [27]. A previous report stated that the increase in oxidative stress in $A D$ was due to an increase in lipid peroxidation and a decrease in antioxidant levels [21]. The antioxidant properties of COFE (Figure S2) could reduce oxidative stress and thus disrupt the pro-inflammatory microenvironment through ROS-mediated signaling events.

Loganin, the main bioactive constituent in COFE, synergistically contributes to the inhibition of oxidative stress, inflammation, and metabolic disorders [28]. It may directly promote the differentiation of MC3T3-E1 cells and inhibit their apoptosis [29]. Cornuside attenuates LPS-induced inflammatory cytokines through the inhibition of NF- $\mathrm{kB}$ activation in RAW 264.7 cells [30]. Moreover, cornuside shows remarkable antioxidant activity and inhibits isoproterenol-induced myocardial cell necrosis [31]. Interestingly, naringenin 7-O- $\beta$-D-glucoside (identified and isolated from Marrubium globosum Montbr. et Auch. ex Benth. ssp. libanoticum Boiss. (Lamiaceae), a medicinal plant used to treat inflammatory diseases and asthma), shows antibacterial activity in several bacterial strains [32]. Besides, naringenin 7-O- $\beta$-D-glucoside has been reported for its antioxidant activity [33]. These compounds may act synergistically to confer various bioactivities to COFE. Molecular docking analysis was carried out to elucidate the interaction between the FceR1-IgE complex and the bioactive compounds identified in COFE.

The best poses of FceR1-IgE docked with loganin, cornuside, and naringenin 7-O- $\beta$-D-glucoside were determined. Interestingly, the docking analysis showed that loganin, being the major component found in this extract, binds to IgE through hydrogen bonds with ARG334, VAL336, ASP362, LEU363, and ALA364 (Figure 3E). It is noteworthy that, in humans, the disruption of the glycosylation site 
at asparagine-394 (ASN394) in the Ce3 domain nullifies the binding of IgE to FceR1 [34]. From our simulation analysis, the binding site of loganin to the complex was the nearest to ASN394, which might indirectly disrupt the formation of the FceR1-IgE complex. Conversely, cornuside possessed the lowest binding energy ( $-141.1 \mathrm{Kcal})$ among the compounds tested (Table 2). A lower energy value represents a higher receptor-ligand binding affinity. In other words, cornuside forms a more stable receptor-ligand complex with FceR1-IgE compared to loganin and naringenin 7-O- $\beta$-D-glucoside. The region where naringenin $7-O-\beta-\mathrm{D}$-glucoside interacts with IgE was further analyzed by the protein sequences in ChimeraX. The protein sequences were then searched against the conserved domain database (CDD) [35]. We found that naringenin 7-O- $\beta$-D-glucoside binds to the $\mathrm{CH} 2$ domain (second constant Ig domain of the heavy chain) of IgE, cd05847. Therefore, the binding of naringenin 7-O- $\beta$-D-glucoside could prevent the conformation change of IgE, subsequently disrupt the engagement of the second $\mathrm{C} \varepsilon 3$ domain to FceR1, and lead to a reduction of skin inflammation.

Our findings suggest diverse potential dermatologic and cosmetic applications for COFE. In silico findings suggest that the bioactive compounds found in COFE impede skin inflammation by disrupting the binding of IgE to the human high-affinity IgE receptors (FceRI). Since our study relies only on in vitro assays, further studies using animal models or artificial skin models would confirm the therapeutic effects and mechanisms of action of COFE.

\section{Conclusions}

Our results show that COFE might exert inhibitory effects on oxidative stress, allergic responses, and inflammatory responses. Additionally, loganin, cornuside, and naringenin 7-O- $\beta$-D-glucoside were identified as compounds potentially responsible for these effects. COFE showed antioxidant, anti-allergic, and anti-inflammatory effects that could potentially be leveraged to treat AD, yet did not exert cytotoxicity or acute oral toxicity. Our findings suggest that COFE could be used in the development of preventative and treatment therapies for AD.

Supplementary Materials: The following are available online at http://www.mdpi.com/2072-6643/12/11/3317/s1, Supplementary Figure S1: The experimental timeline for $\beta$-Hexosaminidase release assay using RBL-2H3 cells (A); $\mathrm{NO}$ assay and isolation of iNOS protein (B) and isolation of $\mathrm{IkB} \alpha$ and p-p65 protein for Western blot analysis (C) in RAW264.7 cells; flow cytometric analysis for apoptosis assay using HaCaT cells (D). Supplementary Figure S2: Evaluation of the extracts' 2,2-diphenyl-1-picrylhydrazyl (DPPH) radical scavenging activity (left). After the incubation of the samples and the DPPH solution at $37^{\circ} \mathrm{C}$ for $30 \mathrm{~min}$, the absorbance at $517 \mathrm{~nm}$ was measured; ascorbic acid was used as a positive control. For the ferric reducing antioxidant power (FRAP) assay (middle), after the incubation of the samples and FRAP reagent at $37^{\circ} \mathrm{C}$ for $30 \mathrm{~min}$, the absorbance at $595 \mathrm{~nm}$ was measured. For the ABTS assay (right), after mixing the ABTS solution and the samples, the absorbance at $734 \mathrm{~nm}$ was measured. The results are expressed as $\mu \mathrm{M}$ Trolox equivalent (TE), Emax, and EC50 $(n=3)$. Letters $(\mathrm{a}-\mathrm{c})$ indicate significantly different values $(p<0.05)$, as determined by Duncan's multiple comparison test. Supplementary Figure S3: Cells were treated with COFE $(0-0.3 \mathrm{mg} / \mathrm{mL})$ for $30 \mathrm{~min}$ and then treated with LPS $(1 \mu \mathrm{g} / \mathrm{mL}) \mathrm{for}$ $18 \mathrm{~h}$. The levels of iNOS were determined by Western blotting of the total protein of cell lysates. $\beta$-actin was used as a loading control. Values are expressed as the mean \pm SD of three independent experiments. Letters $(\mathrm{a}-\mathrm{d})$ indicate significantly different values $(p<0.05)$, as determined by Duncan's multiple comparison test. Reserved DOI:10.5281/zenodo.4065293

Author Contributions: Conceptualization, S.-C.P., Y.Q., and S.-J.L.; methodology, S.-J.L., Y.Q., E.-B.L., B.T.B., M.S.A., M.A.A., N.B. and Z.-E.I.; software, S.-J.L. and Y.Q.; validation, B.T.B. and Z.-E.I.; investigation, S.-J.L., Y.Q., E.-B.L.; resources, Z.-E.I.; data curation, B.T.B.; writing-original draft preparation, S.-J.L. and Y.Q.; writing-review and editing, Y.Q.; supervision, S.-C.P.; funding acquisition, S.-C.P. All authors have read and agreed to the published version of the manuscript.

Funding: This research was supported in part by the Forest Resources Development Institute of Gyeongsangbuk-do and in part The National Research Foundation of Korea (NRF) funded in part by the Ministry of Education (2019R1A2C2006277), Republic of Korea. The funders had no role in study design, data collection, and interpretation, or the decision to submit the work for publication.

Acknowledgments: The authors wish to thank Yuan Yee Lee and Muhammad Irfan for providing technical support.

Conflicts of Interest: The authors declare no conflict of interest. 


\section{References}

1. Brandt, E.B.; Sivaprasad, U. Th2 Cytokines and atopic dermatitis. J. Clin. Cell. Immunol. 2011, 2, 110.

2. Leung, D.Y.M.; Bieber, T. Atopic dermatitis. Lancet 2003, 361, 151-160.

3. Cooper, K.D. Atopic dermatitis: Recent trends in pathogenesis and therapy. J. Investig. Dermatol. 1994, 102, 128-137.

4. Hwang, K.A.; Hwang, Y.J.; Song, J. Antioxidant activities and oxidative stress inhibitory effects of ethanol extracts from Cornus officinalis on raw 264.7 cells. BMC Complement. Altern. Med. 2016, 16, 196.

5. Mechesso, A.F.; Lee, S.J.; Park, N.H.; Kim, J.Y.; Im, Z.E.; Suh, J.W.; Park, S.C. Preventive effects of a novel herbal mixture on atopic dermatitis-like skin lesions in BALB/c mice. BMC Complement. Altern. Med. 2019, 19, 25.

6. Czerwińska, M.E.; Melzig, M.F. Cornus mas and Cornus officinalis-Analogies and differences of two medicinal plants traditionally used. Front. Pharmacol. 2018, 9, 894.

7. Juckmeta, T.; Thongdeeying, P.; Itharat, A. Inhibitory effect on $\beta$-Hexosaminidase release from RBL-2H3 cells of extracts and some pure constituents of Benchalokawichian, a Thai herbal remedy, used for allergic disorders. Evid.-Based Complement. Altern. Med. ECAM 2014, 2014, 828760.

8. Chang, Z.Q.; Hwang, M.H.; Rhee, M.H.; Kim, K.S.; Kim, J.C.; Lee, S.P.; Jo, W.S.; Park, S.C. The in vitro anti-platelet, antioxidant and cellular immunity activity of Phellinus gilvus fractional extracts. World J. Microbiol. Biotechnol. 2008, 24, 181-187.

9. Benzie, I.F.; Strain, J.J. The ferric reducing ability of plasma (FRAP) as a measure of "antioxidant power": The FRAP assay. Anal. Biochem. 1996, 239, 70-76.

10. Rufino, M.D.S.M.; Alves, R.E.; de Brito, E.S.; Pérez-Jiménez, J.; Saura-Calixto, F.; Mancini-Filho, J. Bioactive compounds and antioxidant capacities of 18 non-traditional tropical fruits from Brazil. Food Chem. 2010, 121, 996-1002.

11. Lee, S.J.; Hossaine, M.D.A.; Park, S.C. A potential anti-inflammation activity and depigmentation effect of Lespedeza bicolor extract and its fractions. Saudi J. Biol. Sci. 2016, 23, 9-14. [CrossRef]

12. Endale, M.; Park, S.C.; Kim, S.; Kim, S.H.; Yang, Y.; Cho, J.Y.; Rhee, M.H. Quercetin disrupts tyrosine-phosphorylated phosphatidylinositol 3-kinase and myeloid differentiation factor-88 association, and inhibits MAPK/AP-1 and IKK/NF-KB-induced inflammatory mediators production in RAW 264.7 cells. Immunobiology 2013, 218, 1452-1467. [CrossRef] [PubMed]

13. Xu, W.; Zhang, J.; Zhu, D.; Huang, J.; Huang, Z.; Bai, J.; Qiu, X. Rapid separation and characterization of diterpenoid alkaloids in processed roots of Aconitum carmichaeli using ultra high performance liquid chromatography coupled with hybrid linear ion trap-Orbitrap tandem mass spectrometry. J. Sep. Sci. 2014, 37, 2864-2873. [PubMed]

14. Hossain, M.A.; Lee, S.J.; Park, J.Y.; Reza, M.A.; Kim, T.H.; Lee, K.J.; Suh, J.W.; Park, S.C. Modulation of quorum sensing-controlled virulence factors by Nymphaea tetragona (water lily) extract. J. Ethnopharmacol. 2015, 174, 482-491. [CrossRef]

15. OECD/OCDE. Acute Oral Toxicity-Acute Toxic Class. Method OECD Guideline for the Testing of Chemicals; OECD/OCDE: Paris, France, 2001; pp. 1-14.

16. Berman, H.M.; Westbrook, J.; Feng, Z.; Gilliland, G.; Bhat, T.N.; Weissig, H.; Shindyalov, I.N.; Bourne, P.E. The Protein Data Bank. Nucleic Acids Res. 2000, 28, 235-242. [PubMed]

17. Holdom, M.D.; Davies, A.M.; Nettleship, J.E.; Bagby, S.C.; Dhaliwal, B.; Girardi, E.; Hunt, J.; Gould, H.J.; Beavil, A.J.; McDonnell, J.M.; et al. Conformational changes in IgE contribute to its uniquely slow dissociation rate from receptor FceRI. Nat. Struct. Mol. Biol. 2011, 18, 571-576. [CrossRef] [PubMed]

18. Chen, B.-H.; Hung, M.-H.; Chen, J.Y.-F.; Chang, H.-W.; Yu, M.-L.; Wan, L.; Tsai, F.J.; Wang, T.-P.; Fu, T.-F.; Chiu, C.-C. Anti-allergic activity of grapeseed extract (GSE) on RBL-2H3 mast cells. Food Chem. 2012, 132, 968-974. [CrossRef]

19. Yoo, J.M.; Kim, N.Y.; Seo, J.M.; Kim, S.J.; Lee, S.Y.; Kim, S.K.; Kim, H.D.; Lee, S.W.; Kim, M.R. Inhibitory effects of mulberry fruit extract in combination with naringinase on the allergic response in IgE-activated RBL-2H3 cells. Int. J. Mol. Med. 2014, 33, 469-477. [CrossRef]

20. Yoo, J.M.; Yang, J.H.; Yang, H.J.; Cho, W.K.; Ma, J.Y. Inhibitory effect of fermented Arctium lappa fruit extract on the IgE-mediated allergic response in RBL-2H3 cells. Int. J. Mol. Med. 2016, 37, 501-508. [CrossRef] 
21. Sivaranjani, N.; Rao, S.V.; Rajeev, G. Role of reactive oxygen species and antioxidants in atopic dermatitis. J. Clin. Diagn. Res. 2013, 7, 2683-2685. [CrossRef]

22. Hwang, Y.J.; Lee, E.J.; Kim, H.R.; Hwang, K.A. In vitro antioxidant and anticancer effects of solvent fractions from Prunella vulgaris var. lilacina. BMC Complement. Altern. Med. 2013, 13, 310. [CrossRef]

23. Valledor, A.F.; Comalada, M.; Santamaría-Babi, L.F.; Lloberas, J.; Celada, A. Macrophage proinflammatory activation and deactivation: A question of balance. Adv. Immunol. 2010, 108, 1-20.

24. Shin, J.H.; Chung, M.J.; Seo, J.G. A multistrain probiotic formulation attenuates skin symptoms of atopic dermatitis in a mouse model through the generation of CD4+Foxp3+ T cells. Food Nutr. Res. 2016, 60, 32550. [CrossRef] [PubMed]

25. Gilfillan, A.M.; Beaven, M.A. Regulation of mast cell responses in health and disease. Crit. Rev. Immunol. 2011, 31, 475-529. [CrossRef] [PubMed]

26. Bertino, L.; Guarneri, F.; Cannavò, S.P.; Casciaro, M.; Pioggia, G.; Gangemi, S. Oxidative stress and atopic dermatitis. Antioxidants 2020, 9, 196. [CrossRef]

27. Yidong, T.; Taihao, Q. Oxidative stress and human skin connective tissue aging. Cosmetics 2016, 3, 28.

28. Yokozawa, T.; Kang, K.S.; Park, C.H.; Noh, J.S.; Yamabe, N.; Shibahara, N.; Tanaka, T. Bioactive constituents of Corni Fructus: The therapeutic use of morroniside, loganin, and 7-O-galloyl-D-sedoheptulose as renoprotective agents in type 2 diabetes. Drug Discov. Ther. 2010, 4, 223-234. [PubMed]

29. Li, M.; Wang, W.; Wang, P.; Yang, K.; Sun, H.; Wang, X. The pharmacological effects of morroniside and loganin isolated from Liuweidihuang Wan, on MC3T3-E1 cells. Molecules 2010, 15, 7403-7414. [CrossRef]

30. Choi, Y.H.; Jin, G.Y.; Li, G.Z.; Yan, G.H. Cornuside suppresses lipopolysaccharide-induced inflammatory mediators by inhibiting nuclear factor-kappa B activation in RAW 264.7 macrophages. Biol. Pharm. Bull. 2011, 34, 959-966. [CrossRef]

31. Huang, F.H.; Zhang, X.Y.; Zhang, L.Y.; Li, Q.; Ni, B.; Zheng, X.L.; Chen, A.J. Mast cell degranulation induced by chlorogenic acid. Acta Pharmacol. Sin. 2010, 31, 849-854. [CrossRef]

32. Rigano, D.; Formisano, C.; Basile, A.; Lavitola, A.; Senatore, F.; Rosselli, S.; Bruno, M. Antibacterial activity of flavonoids and phenylpropanoids from Marrubium globosum ssp. libanoticum. Phytother. Res. 2007, 21, 395-397.

33. Orhan, D.D. Novel flavanone glucoside with free radical scavenging properties from Galium fissurense. Pharm. Biol. 2003, 41, 475-478.

34. Balbino, B.; Conde, E.; Marichal, T.; Starkl, P.; Reber, L.L. Approaches to target IgE antibodies in allergic diseases. Pharmacol. Ther. 2018, 191, 50-64. [CrossRef] [PubMed]

35. Lu, S.; Wang, J.; Chitsaz, F.; Derbyshire, M.K.; Geer, R.C.; Gonzales, N.R.; Gwadz, M.; Hurwitz, D.I.; Marchler, G.H.; Song, J.S.; et al. CDD/SPARCLE: The conserved domain database in 2020. Nucleic Acids Res. 2020, 48, D265-D268. [CrossRef]

Publisher's Note: MDPI stays neutral with regard to jurisdictional claims in published maps and institutional affiliations.

(C) 2020 by the authors. Licensee MDPI, Basel, Switzerland. This article is an open access article distributed under the terms and conditions of the Creative Commons Attribution (CC BY) license (http://creativecommons.org/licenses/by/4.0/). 